|IIIIIIIIIIIIIIIIIIIIIIIIIII

ミニレビュー

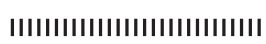

\title{
ケミカルバイオロジー研究法による殺虫剤の分子設計と毒理学"
}

\author{
冨澤元 博* \\ 東京農業大学生命科学部分子生命化学科
}

（2016年11月 14 日受理）

\section{Molecular design and toxicology of insecticides facilitated by chemical biology approaches}

\author{
Motohiro Tomizawa \\ Department of Chemistry, Faculty of Life Sciences, Tokyo University of Agriculture, Tokyo 156-8502, Japan
}

\begin{abstract}
Keywords: cannabinoid receptor, nicotinic acetylcholine receptor, nicotinic and organophosphate insecticides, fatty
\end{abstract} acid amide hydrolase.

\section{はじめに}

有機化学，生命科学，そして分析技術の進歩により本当の 意味でのケミストリーとバイオロジーの融合が可能となり, 近年，ケミカルバイオロジーと呼ばれる分野が動き出した. ケミカルバイオロジーは, ケミカル・アトミックなスケール で生命現象を理解するという目的において，ケミストリーの 論理や研究戦略を積極的に応用するというものである。とく に小分子有機化合物（広義の薬物）を分子プローブとして用 いることで，リガンドと標的タンパク質との三次元相互作用 が定義でき，そして薬物結合表面の立体構造から合理的なド ラッグデザインが可能となる。一方，未同定の薬物ターゲッ トを釣り上げるために薬物構造を基盤とした分子プローブを 用いることで薬物による生体影響発現メカニズムの解明にも 貢献することができる，本稿では，著者の研究グループから 発表された二つの話題，すなわち，新奇ファルマコフォアを

\footnotetext{
\#第41回大会シンポジウムを取りまとめた解説.

* = 156-8502 東京都世田谷区桜丘 1-1-1

E-mail: mt204882@nodai.ac.jp

(c) 日本農薬学会
}

有するニコチン性殺虫剤のデザインと有機リン酸エステル化 合物による雄性生殖毒性ターゲットの同定について紹介いた します。なお，研究背景についての情報は本稿に引用した原 著文献をご参照いただきたい。

\section{1．ニコチン性殺虫剤のデザイン}

\section{1. ニコチン性アセチルコリン受容体薬物結合表面の定義}

ニコチンやエピバチジンのようなニコチン性のアルカロイ ドならびにネオニコチノイド系殺虫剤の作用点であるニコチ ン性アセチルコリン受容体は, 神経伝達物質作動性イオン チャンネルであり, 即動的な興奮性の神経伝達を媒介する. 本受容体は, 五つのサブュニットから構成され, 神経シナプ ス膜を貫通している．細胞外に突き出た部分にはアセチルコ リンやニコチン性化合物の結合ポケットがあり, 膜貫通部分 の内側はイオンチャンネルをなす。 アセチルコリンやニコチ ンの結合ポケットは $\alpha$-サブユニット $[(+)$ 鎖 $]$ と非 $\alpha$-サブ ユニット [(-) 鎖 $]$ の境界領域に存在する. サブユニット 境界領域にある薬物結合ポケットは, アミノ酸配列のうえで 非連続的な6箇所のループと呼ばれるアミノ酸数個分程度か らなる特定部位が空間的にポケットの内壁を作る。すなわ ち， $\alpha$-サブユニット $[(+)$ 鎖 $]$ 側のループ A, B, C と, 非 $\alpha$ - 
サブユニット $[(-)$ 鎖 $]$ 側にあるループ D, E, F とが薬物分 子との相互作用に直接関与する. ニコチン受容体のタンパク 質構造は, シビレエイ電気器官由来受容体の低温電子顕微鏡 観察によって可視化されていた。この方法ではタンパク質の 機能構造変化などマクロな動きを捉えるには十分な解像度を 持つが，低分子有機化合物と結合部位のアミノ酸との相互作 用を定義するには不十分である，その後，ヨーロッパモノア ラガイやアメフラシなどのような軟体動物の神経伝達系にお いて，シナプスのアセチルコリン濃度を調節する水溶性タン パク質としてアセチルコリン結合タンパク質が発見され，そ の結晶構造が解明された。このアセチルコリン結合タンパク 質は，ニコチン受容体のように 5 量体構造をとっているが, イオンチャンネルを持たない。ちょうど受容体のアセチルコ リン結合ポケットがある細胞外領域だけを切り取ったような 構造をしている．また，受容体のように二コチン性リガンド の結合ポケットはサブュニット境界領域にあり，6つのルー プおよび鍵となるアミノ酸も保存されている．以上のことか ら，これまで詳しい解析ができなかったニコチン性化合物の 結合ポケットでの相互作用を定義することが可能になった。

一般的に薬物の結合機序にアプローチする場合，任意のア ミノ酸またはアミノ酸群（キメラ）の変異による薬効変化を比 較する方法が最も容易である。しかし薬物結合ポケットは複雑 な三次元構造を形成するために，その薬効変化が変異に直接 帰属可能か，または結合表面の間接的構造変化によるものなの

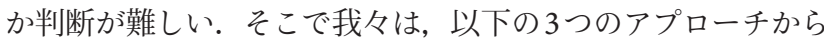
得られるデータを総合することにより精緻な解析が可能になる と考えて，ニコチン性アルカロイド型リガンドおよびネオニコ チノイドの結合部位相互作用を定義することにした ${ }^{1-5)}$. 第一 は, 高解像度で結果が得られる薬物とアセチルコリン結合タン パク質との共結晶構造の解析である（ただし結晶化後の状態 を観ているため生理的条件下での相互作用を反映しない場合 もある). その結果，上述の薬物相互作用に関して鍵になるア ミノ酸のジオメトリーや薬物結合によるタンパク質のコンフォ メーション変化，水分子の会合を捉えることができた ${ }^{4)}$. 第二 は，アセチルコリン結合タンパク質のニコチン性リガンド型プ ローブによる光親和性標識法である。このケミカルアプローチ は，水溶液中での実験が可能であり，薬物の標識位置を質量 分析法等で同定できる，そして標識位置の同定を通じてニコチ ン性リガンドの結合部位相互作用の三次元イメージのマッピン グに成功した。本光親和性標識法は薬物分子を結合部位内に 直接固定化する方法であるが，一方ではアミノ酸と光活性化 により発生した化学種との反応性バイアス（反応しやすき）が かかる場合がある ${ }^{1-3)}$ ．そこで第三として，同定した標識位置 近傍のアミノ酸を個々に光活性化した化学種と反応性の高いア ミノ酸に変異（スキャニング）させて，プローブによる標識位 置がシフトするか否かをチェックした，その結果，反応性の高 いアミノ酸がどの位置にあっても標識されるわけではなく，特
異的な位置・方向でプローブの標識化が起こっている，すなわ ち, 薬物の特異的な相互作用を反映していることを確かめた ${ }^{5)}$.

\section{2. ニコチン受容体タンパク質構造をガイドとした化合 物のデザイン}

ネオニコチノイドが結合部位にドッキングした状態の受容 体の三次元構造情報が得られたことで, 新奇なファルマコ フォアをもつリガンドのデザインが容易になる（図 1-1)。こ のコンセプトを例証する目的でいくつかの化合物をデザイン した ${ }^{6-11)}$.アセチルコリン結合タンパク質の情報を基盤にして 樹立された昆虫ニコチン受容体のアゴニスト結合ポケットの 立体構造をイメージすると，ネオニコチノイドのニトロまた はシアノイミンは, サブュニット境界にある結合ポケットの $\alpha$-サブユニット側のループC部分と主に相互作用する．興味 深いことに, 部分陰性荷電が集まるニトロ／シアノ先端酸素 または窒素原子から非 $\alpha$-サブユニット側のループ D の方向に 4-6 程度のニッチ（くぼみ）が存在する.ささらそその空間の 終点には水素供与体であるアルギニンがある（図1-2），そこ で，このギャップを埋めることができて，さらに水素結合可 能な窒素原子をもった新奇ファルマコフォアとして，ピラジ ノイルイミンを導入したリガンドを合成したところ，イミダク ロプリドやチアクロプリドょりも高い結合親和性を示し，高 い殺虫効果を呈した（図1-4）。さらに，ループC拈よびDエ リアのアミノ酸と多角的に水素結合や疎水性結合を形成させ るため, トリフルオロアセチルイミンおよびフッ素以外のハロ ゲン原子を入れた八ロアセチルイミン型の化合物をデザイン した（図1-5）。これらの化合物は受容体への親和性が高いが, 八ロゲンが導入されていないアセチルイミン体では親和性が 落ちる。また驚くべきことに，八ロアセチルイミン体は分子 の疎水性が増大しており，比較的親水性の高いイミダクロプ リドやチアクロプリドでは認められない昆虫への顕著な接触 毒性を呈した。一方, 昆虫受容体の $\beta$-サブユニット側のルー プDアルギニン部分がトレオニンに置き換わっている脊椎動 物の $\alpha 4 \beta 2$ 受容体に対して, 上述のピラジノイルイミンおよび トリフルオロアセチルイミン化合物の親和性は予想通り低く, マウスへの毒性も低いことがわかった，興味深いことに，昆 虫 $\alpha$-サブユニットと脊椎動物 $\beta 2$-サブユニットからなるハイブ リッド受容体に対して, これらアシルイミン化合物の親和性 は低い，一方，昆虫 $\alpha$-サブュニット側のループCと主に相互 作用するニトロイミン/シアノイミンをもつネオニコチノイド のハイブリッド受容体への結合親和性は高い，すなわち，こ れらの新奇ファルマコフォアを導入することにより, 昆虫受 容体 $\beta$-サブユニット上のループDアミノ酸との間に選択的な 相互作用をつくることができたと考えられる ${ }^{6,7,11)}$.

さらに上述のアシルイミンをアリールオキシカルボニルイ ミンに改変 (カルボニル部分の次に回転可能なエーテル結 合を介して芳香環をつけたもの）することで（図1-6），ルー 


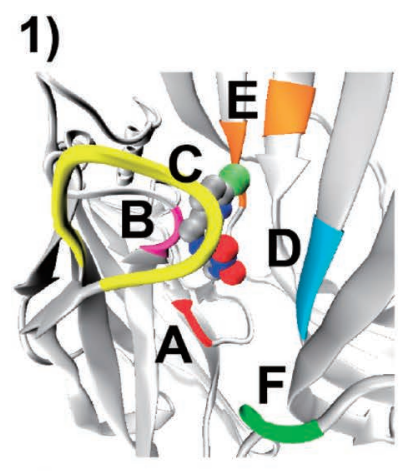

4)

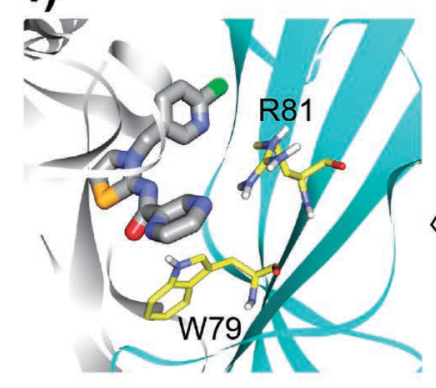

6)
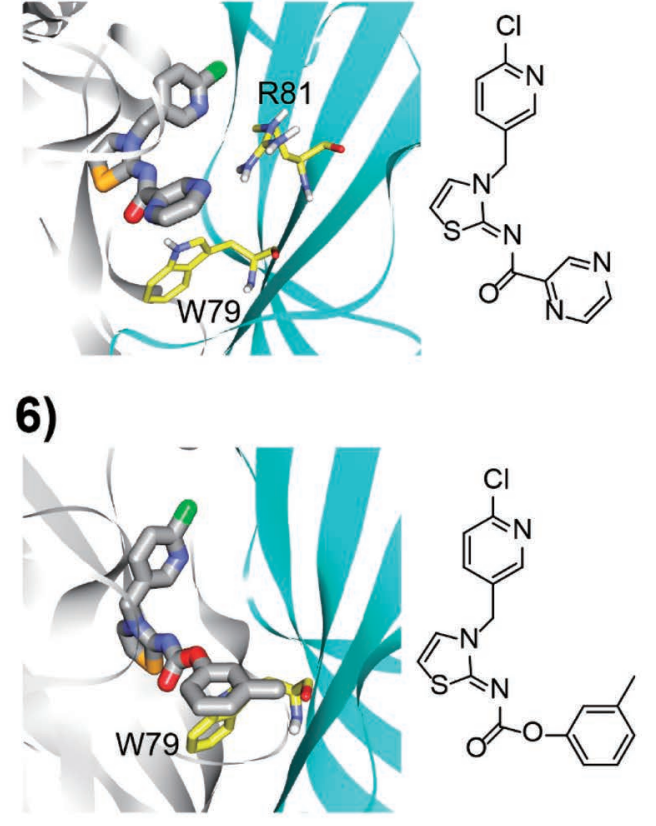

2)

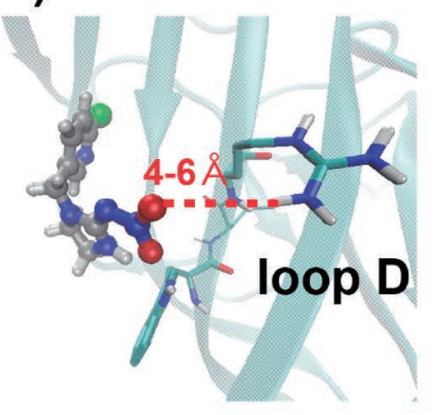

3)

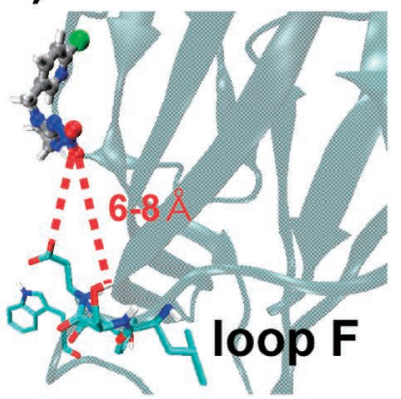

5)
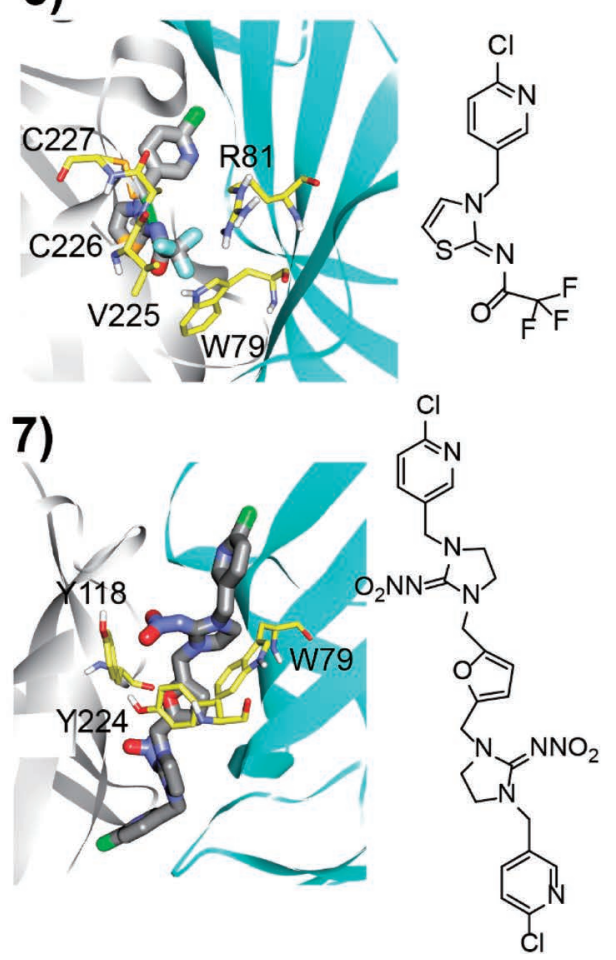

図1. ニコチン性アセチルコリン受容体の三次元構造をガイドとしたドラッグデザイン. 昆虫ニコチン受容体モデル（モモアカアブラムシ $\alpha 2 \beta 1$ 境界領域）は，昆虫受容体サロゲートであるアメフラシのアセチルコリン結合タンパク質の結晶構造を鋳型として樹立された（PDB 3C79). 昆虫受容体のサブユニット構成は不明であるが，アゴニスト結合ポケット内壁を構成する主要アミノ酸は脊椎動物，昆虫，アセチル コリン結合タンパク質の間ではほとんど同じか機能的役割が同じものである．1）イミダクロプリドが結合部位に結合した様子を示す．図中 の A から F は薬物結合ポケットの内壁で薬物と直接コンタクトするアミノ酸のある領域. 2) イミダクロプリドのニトロ酸素からループ $\mathrm{D} ア ~$ ルギニン（R81）に向かって存在するニッチ（くぼみ）．3）イミダクロプリドのニトロ酸素からループF方向に広がる空間．4）ピラジノイ ル部分はループDトリプトファン（W79）やアルギニンと相互作用し， 5）トリフルオロアセチル部分はループC（V225やC226）およびD アミノ酸と主に相互作用する．6）3-メチルフェノキシカルボニル型化合物のフェニル環とループDトリプトファンのインドール環とはfaceto-edge スタッキングする．7）ループF空間にも相互作用するフランジメチレンリンカーを持つビスイミダクロプリドのフラン部分は，ルー プA, C, Dの三つの芳香族アミノ酸（Y118, Y224, W79）からなる疎水性ポケットに収容される.

プDトリプトファン芳香環とのルースタッキング（ $\pi$ - $\pi$ 相互作 用）をある程度自由に起こさせることが可能になるとの仮説 を検証した．最も高い親和性を示したものは，3-メチル置換 フェノキシカルボニルイミンであった. 実際, ベンゼン環に 電子供与性基があるものでは親和性が上がり, 電子吸引性基 があるものでは薬効が下がるという結果となり, ベンゼン環 内の電子密度が高い方がトリプトファンの $\pi$-電子系とスタッ クしやすいことがわかる.しかしながら，アリールオキシカ
ルボニルイミン型化合物は, 受容体への親和性が十分に高く ても加水分解を受けやすいため殺虫活性はむしろ低かった ${ }^{9)}$.

イミダクロプリドが受容体に結合した構造モデルにおい て, ニトロ酸素の下方, すなわちループF方向にはさらに 6-8 程度の深さの空間が存在する（図 1-3）．そこでループ $\mathrm{F}$ 方向にアンカーとして作用する置換基をもつ化合物のデザ インに取り組んだ。最初にイミダクロプリド2分子をへキサ メチレンリンカーで連結したビス体がループF部分にコンタ 
クトすることで比較的高い受容体相互作用を示すとの結果 を得た ${ }^{8)}$. ところが, ヘキサメチレンリンカーの役割は, 単 に2分子のイミダクロプリドを連結しているだけであること から，リンカー部分にも受容体サイドと相互作用することが できる構造部分に改変する必要があると考えた．本ビス体が 結合したとき, リンカー部分の近傍にはループ A, C, D由来 の三つの芳香族アミノ酸が向かい合うような空間配置をとる ことから，この三つの芳香環からできる疎水性ポケットと相 互作用できるリンカーとしてフランジメチレン部分をもつ化 合物をデザインした（図1-7）。予想通り，本化合物はビス イミダクロプリドシリーズの中で最も受容体への親和性が高 く, 殺虫活性も比較的高かった ${ }^{10)}$.

\section{2. 有機リン殺虫剂による雄性生殖毒性ターゲット}

有機リン酸エステル殺虫剤（OP）は, 農業生産に加え, 森 林保護（松枯机対策として空中散布）や衛生環境維持（屋内 外の消毒）などのために世界中で最も汎用されている．例え ば，東日本大震災の被災地では八エや蚊が爆発的に発生し， OP剤が防疫活動に不可欠であった。このように OP剂に頼ら ざるをえない状況が農業生産以外のところでは生じている. したがって小児から大人まで日常生活を通じて様々な経路か らの曝露が想定される。OP剂による急性神経毒性についての 理解は十分であるが, 近年, 致死・中毒の顕れる用量より低 いレベルで持続的に曝露された場合に起こる健康影響につい て危惧されている．OP化合物は，急性神経毒性の標的である アセチルコリンエステラーゼだけでなく, 多様なセリン加水 分解酵素にも潜在的に作用しうることから, OP剂や OP化合 物曝露による急性神経毒性以外のターゲットの探索研究を行 うことは重要である.このような加水分解酵素には, リパーゼ などのように脂質代謝に関与するものが多く，OPは脂質ホメ オスタシスを攪乱する可能性が高いと言える，また脂質は性 ホルモンの原料でもあることから, OPによる脂質恒常性の擋 乱と生殖器影響の関係も注目される. ヒトの雄性生殖系は $\mathrm{OP}$ 剂の二次ターゲットの一つであると考えられており, 多くの疫 学研究により環境要因（生活・職業など）による OP剂と雄性 生殖毒性，とくに精子毒性との関連が示唆されていた。また 殺虫剂散布作業者に有意な精子運動性の低下が見られること やOP剂を投与したラットでも, 精子運動性の低下や精子奇形 率の上昇が見られることが報告されている，以上のことを総 合すると, OP剂曝露による精子毒性は, OP活性体が雄生殖 器内の特異的なリパーゼ類（または複数のターゲット）をブ ロックし, 脂質代謝系を攪乱させることで起こるという仮説 が成り立つ，そこで我々のグループでは，ケミカルバイオロ ジーアプローチによりマウスやラットの雄性生殖器官中の潜 在的な OP化合物ターゲットの探索に取り組んだ ${ }^{12-14)}$.

アルキルフルオロフォスフォリデート化合物はリン酸化能 力が高いことから，そのアルキル部分にスペーサーを介して
蛍光発色基を導入した OPケミカルプローブを用いることによ り, 対象とする器官や組織中の $\mathrm{OP}$ 化合物がリン酸化しうるセ リン加水分解酵素のほとんどを網羅的に検出することができ る. そこでまずマウス精巣プロテオームと OP活性体（オキソ ン）を反応させ, OP化合物に特定のターゲットとのリン酸化 反応を起こさせる．次いで上述の OP ケミカルプローブを反応 させて, 電気泳動後, OP ケミカルプローブによる標識パター ンを観察する。供試した $\mathrm{OP}$ 化合物は既に特定のターゲットと 反応していることから OPケミカルプローブは，そのターゲッ
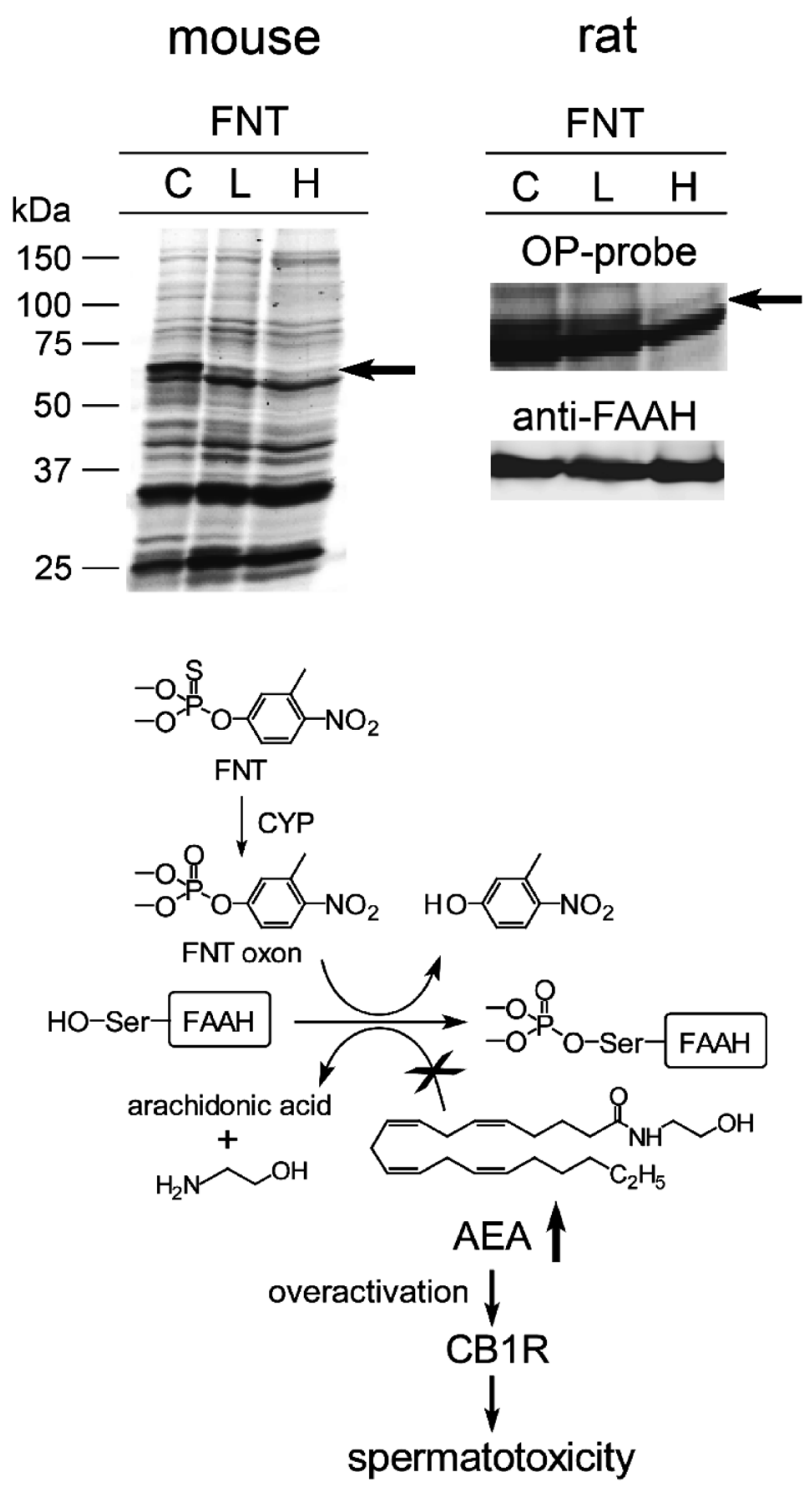

図2.フェニトロチオン（FNT）のマウスまたはラット精巣由来 セリン加水分解酵素プロテオームへの影響と FNT 曝露による精 子毒性発現機序仮説. マウス（左上）での OP プローブによる標 識結果は電気泳動ゲル全体（20-200 kDa）を示している。ラッ 卜（右上）では, FAAH $(63 \mathrm{kDa})$ 付近のみを抽出した OPプ ローブ標識イメージと FAAH抗体で検出した発現レベルを示し ている．FNT投与レベルのC，L，Hは，それぞれ対照群，低用量 群, 高用量群を表す。AEAはアナンダミド, CB1Rは1型カンナ ビノイド受容体の略称. 
トを標識できない. したがって，OPケミカルプローブによる 標識が消失した部分こそが OP化合物の潜在的ターゲットと なる.この原理に基づきフェニトロオキソンのマウス精巣プ ロテオーム中のターゲットをインビトロで探索したところ, 脂 肪酸アミド加水分解酵素（FAAH）がヒットした。ちなみに FAAH は内因性のカンナビノイド受容体（Gタンパク質共役 型受容体でマリファナのターゲットとして知られる）アゴニ ストの一つであるアナンダミドを加水分解する酵素である. 次にマウスにフェニトロチオンを 10 日間経口投与した後, OP ケミカルプローブによる精巣プロテオームの標識化を行った ところ，用量依存的にFAAHだけが消失することが判明した (図 2)。さらに, FAAH酵素活性を精巣および成熟した精子が 蓄えられる精巣上体尾部で測定し, 用量依存的な活性低下を 認めた ${ }^{13)}$ 。このことから，その他の坑コリンエステラーゼと して, ジクロルボス, パラオキソン, ダイアジノンオキソン, クロルピリフォスオキソン, カルバリル，プロポキスル，カル ボフランによるインビトロ精巣由来FAAH阻害試験を行った ところ, OP化合物ではFAAHを強く阻害したが，カーバメー ト化合物ではほとんど影響がなかった。 クロルピリフォスオ キソンは, FAAHのほかにモノアシルグリセロールリパーゼ にも作用することがわかった ${ }^{12)}$. 以上のことから，雄性生殖 器官内における OP化合物の主な潜在的ターゲットは, FAAH であるとの結論に達した。

次のステップとして, OP剂曝露による精子毒性がFAAH阻 害と関連するか検討した．精子の成熟までには9週間を要する ことからラットに9週間にわたってフェニトロチオンを経口投 与した（週あたり 4 日間投与）。その後, 精巣上体尾部から得 た精子の数, 運動性, 正常精子数, 未成熟精子数, 奇形 (頭 部や尾部のないもの）精子数などのパラメーターを調べ, 併せ て精巣プロテオームの OPケミカルプローブ標識パターン観察, FAAH活性測定, FAAHが加水分解すべき内因性基質である アナンダミド量を定量した。その結果, 精子毒性パラメーター と FAAH阻害活性との間に有意な相関性を認めた。さらにアナ ンダミド濃度は投与したフェニトロチオンの用量依存的に増加 傾向にあることがわかった，OPケミカルプローブの精巣プロ テオーム標識では, FAAH部分の標識が用量依存的に消失し ているが, FAAHの発現量はコントロールと比べ変化がないこ とが判明した ${ }^{14)}$. 以上の実験から, OP化合物が雄性生殖器官 内の FAAHを阻害し, 内因性基質であるアナンダミドレベルが 上昇することが OP化合物曝露による精子毒性のトリガー機序 であるとの斬新な仮説を提唱した（図2）。したがって，アナン ダミドはカンナビノイド受容体の内因性アゴニストであること から，アナンダミドがカンナビノイド受容体シグナル伝達系を 過克進することで, 精子の成熟に関与するセルトリ細胞などが アポトーシスすることで精子の未成熟や奇形などに繋がり，ま た精子細胞上でもカンナビノイド受容体シグナルへの影響が起 こるため運動性が低下するのではないかと考えられる.

\section{おわりに}

本稿ではケミカルバイオロジー研究法による二つの事例を 紹介させていただいたが，このようなアプローチは薬物ター ゲット分子の同定や薬物の作用表面での結合メカニズムを定 義するためのツールとして大変有用である. 今後もますます ケミストリーの考え方を基盤とする生命科学研究が発展して いくのではないかと思われる. 最後に本稿に紹介させていた だいた仕事内容の共同研究者であるカルフォルニア大学バー クレー校の John E. Casida先生と Kathleen A. Durkin先生, 岐皁大学の利部伸三先生, 名古屋市立大学の上島通浩先生と 伊藤由起先生に感謝いたします.

\section{引用 文 献}

1) M. Tomizawa, D. Maltby, K. F. Medzihradszky, N. Zhang, K. A. Durkin, J. Presley, T. T. Talley, P. Taylor, A. L. Burlingame and J. E. Casida: Biochemistry 46, 8798-8806 (2007).

2) M. Tomizawa, T. T. Talley, D. Maltby, K. A. Durkin, K. F. Medzihradszky, A. L. Burlingame, P. Taylor and J. E. Casida: Proc. Natl. Acad. Sci. U.S.A. 104, 9075-9080 (2007).

3) M. Tomizawa, D. Maltby, T. T. Talley, K. A. Durkin, K. F. Medzihradszky, A. L. Burlingame, P. Taylor and J. E. Casida: Proc. Natl. Acad. Sci. U.S.A. 105, 1728-1732 (2008).

4) T. T. Talley, M. Harel, R. E. Hibbs, Z. Radić, M. Tomizawa, J. E. Casida and P. Taylor: Proc. Natl. Acad. Sci. U.S.A. 105, 7606-7611 (2008).

5) M. Tomizawa, T. T. Talley, J. F. Park, D. Maltby, K. F. Medzihradszky, K. A. Durkin, J. M. Cornejo-Bravo, A. L. Burlingame, J. E. Casida and P. Taylor: J. Med. Chem. 52, 3735-3741 (2009).

6) M. Tomizawa, S. Kagabu, I. Ohno, K. A. Durkin and J. E. Casida: J. Med. Chem. 51, 4213-4218 (2008).

7) I. Ohno, M. Tomizawa, K. A. Durkin, Y. Naruse, J. E. Casida and S. Kagabu: Chem. Res. Toxicol. 22, 476-482 (2009).

8) I. Ohno, M. Tomizawa, K. A. Durkin, J. E. Casida and S. Kagabu: Bioorg. Med. Chem. Lett. 19, 3449-3452 (2009).

9) I. Ohno, M. Tomizawa, N. Miyazu, G. Kushibiki, K. Noda, Y. Hasebe, K. A. Durkin, T. Miyake and S. Kagabu: Bioorg. Med. Chem. Lett. 20, 5933-5935 (2010).

10) S. Kagabu, I. Ohno, M. Tomizawa, K. A. Durkin, R. Matsuura, D. Uchiyama, N. Nagae and S. Kumazawa: J. Agric. Food Chem. 58, 11832-11836 (2010).

11) M. Tomizawa, K. A. Durkin, I. Ohno, K. Nagura, M. Manabe, S. Kumazawa and S. Kagabu: Bioorg. Med. Chem. Lett. 21, 35833586 (2011).

12) Y. Noro, M. Tomizawa, Y. Ito, H. Suzuki, K. Abe and M. Kamijima: Bioorg. Med. Chem. Lett. 23, 5434-5436 (2013).

13) H. Suzuki, M. Tomizawa, Y. Ito, K. Abe, Y. Noro and M. Kamijima: J. Agric. Food Chem. 61, 9961-9965 (2013).

14) Y. Ito, M. Tomizawa, H. Suzuki, A. Okamura, K. Ohtani, M. Nunome, Y. Noro, D. Wang, T. Nakajima and M. Kamijima: Toxicol. Appl. Pharmacol. 279, 331-337 (2014). 